\title{
Maternal Vitamin D Level in Preterm and Term Labouras a Risk Factor
}

\author{
Ahmed Mohammed Tahoun*, TarekAbdElkareim El-Dahshan*, HishamFekry Ahmad Abu- \\ Senah* \& Ahmed Sayed Ahmed Mohammed* \\ *Department of Clinical Pathology, Faculty of Medicine, Al- Azhar University
}

Corresponding author: Ahmed Sayed Ahmed Mohammed, Mobile: 00201096343038, E-Mail: ahm_mido88@yahoo.com Abstract

Background: Preterm birth constitutes 5-18\% of all deliveries and very low birth weight infants comprise $4-8 \%$ of all live births. Significant advances in neonatal care have increased the survival rate of premature infants. However, the associated morbidity continues to affect these infants despite the increased survival rate. Preterm birth is the most important problem in modern obstetrics. More than 1 million infants born preterm (at less than 37 weeks of gestation) died worldwide, making it the second leading cause of death in children under the age of 5 years.

Aim: The aim of this work was to study the role of vitamin D in Egyptian pregnant women at labour to evaluate its predictive value in preterm labour.

Methodology: This study was conducted on 90 subjects of pregnant females at labor. Their ages ranged from 14 to 40 years old. This study was carried out in collaboration of the Clinical Pathology and Obs/Gyna Departments at Al-Hussein and Bab-Elshareyia University Hospitals, Faculty of Medicine, Al-Azhar University. All participants were selected from the Obs/Gyna Department, Al-Hussein and Bab-Elshareyia University Hospitals over a period from April, 2018 to July, 2018. In the present study an attempt was done to determine whether the level of vitamin D in Egyptian pregnant females correlates with preterm labor or not.

Results: Group 1 (study group): Mean vitamin D level is $10.93 \mathrm{ng} / \mathrm{ml} .27$ patients of this group (60\%) were suffering from vitamin D deficiency while the other $15(33.3 \%)$ suffered from vitamin D insufficiency and other $3(6.6 \%)$ had normal vitamin D level. Group 2 (control group):.Mean vitamin $\mathrm{D}$ is $16.15 \mathrm{ng} / \mathrm{ml}$. This study showed highly statistically significant decrease ( $\mathrm{p}$ value $<0.001$ ) in vitamin $\mathrm{D}$ in the study group as compared to control group. 93\% showed abnormally low 25-(OH) D levels for cases having preterm labor where $60 \%$ of patients shows deficient $25-(\mathrm{OH}) \mathrm{D}(<12 \mathrm{ng} / \mathrm{ml}), 33 \%$ of patients showed insufficient $25-(\mathrm{OH}) \mathrm{D}(>20$ and $<30 \mathrm{ng} / \mathrm{ml})$, while $7 \%$ of cases showed normal vitamin D level.

Conclusion: Vitamin D deficiency occurs in the majority of preterm labour cases in Egypt and therefore decreased serum vitamin D levels are considered an additional risk factor in the pregnancy outcome.

Recommendation: For better assessment of vitamin D status, future studies should be done to evaluate serum levels of $\mathrm{Ca}, \mathrm{Ph}$ and PTH to assess the cause of deficiency, which will help in better management. In addition, it is recommended to consider vitamin D supplementation and its efficacy as a new important line of prophylaxis in pregnant females. Thereby prophylactic administration of vitamin D could be useful and researches have to be done to approve this theory. Screening for vitamin D deficiency seems of value in pregnant females.

Keywords: Vitamin D, Preterm labour, Pregnant women

\section{Introduction:}

Preterm birth constitutes 5-18\% of all deliveries and very low birth weight infants comprise 4$8 \%$ of all live births. Significant advances in neonatal care have increased the survival rate of premature infants. However, the associated morbidity continues to affect these infants despite the increased survival rate ${ }^{(\mathbf{1})}$.

Preterm birth is the most important problem in modern obstetrics. More than 1 million infants born preterm (at less than 37 weeks of gestation) died worldwide, making it the second leading cause of death in children under the age of 5 years ${ }^{(2)}$.
Preterm infants who survive are at risk of chronic lung disease, deafness, blindness or other visual impairment, and learning and cognitive disabilities. The $12 \%$ rate of preterm birth in the United States ranks 131 of 184 countries, behind many developing nations ${ }^{(3)}$. The past 3 decades in the United States showed little decline in preterm births, including the earliest deliveries, which cause the most morbidity and mortality. Identifying potential targets for preterm birth prevention is a public health priority ${ }^{(2)}$. Preterm birth, as the largest cause of neonatal deaths worldwide puts surviving children at risk for cerebral palsy, 
behavioral problems, bronchopulmonary dysplasia, retinopathy of prematurity, hearing impairments, increased hospital admissions and academic underachievement ${ }^{(4)}$.

Vitamin D, a secosteroid hormone known for its classical functions in calcium uptake and bone metabolism, is now well recognized for its nonclassical actions, including modulation of innate immune response and regulation of cell proliferation ${ }^{(5)}$.

Vitamin D deficiency, which has long been recognized as a cause of rickets and osteomalacia, has been given increased attention for its noncalcemic roles across the life span, including in pregnancy. Maternal vitamin $\mathrm{D}$ deficiency has been associated with many poor birth outcomes, including fetal growth restriction ${ }^{(\mathbf{6})}$.

A Cochrane review showed that vitamin D supplementation in pregnancy reduces the incidence of low birth weight $(<2.5 \mathrm{~kg})$ by $52 \%$

(7). Studies of the biological marker of vitamin D status, serum 25-hydroxyvitamin D and fetal growth contributed to the evidence of an association, although there have been inconsistencies in findings ${ }^{(8)}$. In a large, multiethnic cohort in the Netherlands, Leffelaaret al. ${ }^{\left({ }^{(9)}\right.}$ showed that risk of small-forgestational age was 2.4 times higher for mothers with 25-(OH)D concentrations $<29.9 \mathrm{nmol} / \mathrm{L}$ compared to $\geq 50 \mathrm{nmol} / \mathrm{L}$ in the first trimester. Fernándezet al. ${ }^{(\mathbf{1 0 )}}$ reported that maternal 25- $(\mathrm{OH}) \mathrm{D}$ concentrations $\geq 37.5$ $\mathrm{nmol} / \mathrm{L}$ compared to $<37.5 \mathrm{nmol} / \mathrm{L}$ at $\leq 26 \mathrm{wk}$ gestation was associated with a 46-g higher term birth weight and in the first trimester was associated with one-half the risk of small-forgestational age at birth.

Maternal vitamin D deficiency has been linked to adverse pregnancy outcomes, including preeclampsia and fetal growth restriction ${ }^{(11)}$.

Vitamin D may be relevant for preterm birth prevention. 1,25dihydroxyvitamin $\mathrm{D}$ is known to reduce bacterial infections by inducing cathelicidin in many tissues, including maternal and fetal cells of the placenta ${ }^{(\mathbf{1 2})}$.

\section{Aim of the work:}

The aim of this work was to study the role of Vitamin D in Egyptian pregnant women at labour to evaluate its predictive value in preterm labour.

\section{Subjects and methods:}

\section{Subjects:}

This study was conducted on 90 subjects of pregnant females at labor, their ages ranged from 14 to 40 years old. The study was carried out in collaboration of the Clinical Pathology and OB/GYN Departments at Al-Hussein and Bab-Elshareyia University Hospitals, Faculty of Medicine, Al-Azhar University.The study was approved by the Ethics Board of AlAzhar University.

All participants were selected from the OB/GYN Department, Al-Hussein and BabElshareyia University Hospitals over a period from April, 2018 to July, 2018.

\section{The study and controls were divided into the following groups:}

Group 1 (case group): Comprising 45 pregnant females in preterm labour $(\leq 37$ weeks gestation).

Group 2 (control group): Comprising 45 apparently healthy pregnant females in fullterm labour.

\section{Exclusion criteria:}

1- Hypertension

2- DM \& gestational glucose intolerance.

3- Eclampsia\& pre-eclampsia.

4- Other secondary cause of pretremlabour

\section{Methods:}

All individuals included in the study were subjected to the following:

Appropriate consent to participate in this study after explanation how much it is helpful in diagnosis and treatment and explaining to the cases that it is just a blood sample collection.

- Full medical history and full clinical examination.

including.

Basic laboratory investigations

1- Complete blood count (CBC).

2- $\quad$ Liver function tests (ALT and AST).

3- $\quad$ Renal function tests (Blood Urea and

Serum Creatinine).

4 - Random blood sugar(RBS)and CRP.

- Specific test: Serum 25-

hydroxyvitamin D level by ELISA.

Statistical analysis of the results. 


\section{Sampling:}

Eight $\mathrm{ml}$ venous blood were withdrawn from each subject and subdivided as follows:

- $2 \mathrm{ml}$ in EDTA tube for routine CBC.

- $6 \mathrm{ml}$ in plain tube was left to clot for 30 minutes, then centrifuged, the serum was separated and divided into two aliquots, one for routine biochemical tests performed on same day of collection by latex, colorimetric and kinetic reaction while the other aliquot was stored deeply frozen at $\left(-20^{\circ} \mathrm{C}\right)$ for estimation of serum 25(OH) D using ELISA.

\section{Basic principles of the routine tests:}

I- Complete blood count (CBC): were done using fully automated cell counter, CellDynRubby and Sysmex Kx-21 (Japan).

II- Routine biochemical tests: using fully automated chemistry autoanalyzer, Biolis 50i superior (Boeki, Tokyo, Japan).

\section{a- $\quad$ Alanine Aminotransferase(ALT):}

Principle: The enzyme alanine aminotransferase catalyzes the transaminase reaction between L-Alanine and 2Oxoglutarate. The formed pyruvate is reduced to lactate in the presence of lactate dehydrogenase (LDH). As the reactions proceed, NADH is oxidized to NAD. The disappearance of NADH per unit time is monitored by measuring the decrease in absorbance at $340 \mathrm{~nm}^{(\mathbf{1 3})}$.

\section{b- Aspartate Aminotransferase (AST):}

Principle: The enzyme aspartate aminotransferase catalyzes the transaminase reaction between L-Aspartate and 2Oxoglutarate. The formed 2- Oxaloacetate is reduced to malate in the presence of malate dehydrogenase (MDH). As the reactions proceed, NADH is oxidized to NAD. The disappearance of NADH per unit time is monitored by measuring the decrease in absorbance at $340 \mathrm{~nm}^{\mathbf{( 1 3 )}}$.

\section{c- Serum creatinine:}

Principle: By Fixed rate colorimetric Jaffe method. Orange complex to be measured between 490 and 500nm.

The rate of dye formation is proportional to the creatinine concentration in the sample ${ }^{(13)}$.

\section{d- Serum Urea:}

Principle: Colorimetric enzymatic method.
The ammonium ions formed react with salicylate and hypochlorite to give a green dye measured at wavelength $578-623 \mathrm{~nm}$.

The intensity of the color formed is proportional to the concentration of urea in the sample ${ }^{(\mathbf{1 4})}$.

e- Random blood glucose level (RBG):

Principle: glucose oxidase method.

The enzyme glucose oxidase catalyzes the oxidation of glucose to gluconic acid and hydrogen peroxide $\left(\mathrm{H}_{2} \mathrm{O}_{2}\right)$. Addition of the enzyme peroxidase and a chromogenic oxygen acceptor, such as $o$-dianisidine, results in the formation of a colored compound that is measured at $540 \mathrm{~nm}^{(15)}$.

\section{f- C-Reactive protein (CRP)}

Principle :latex agglutination

The $\mathrm{C}$ - reactive protein test is based on the principle of the latex agglutination. When latex particles complexed human anti-CRP were mixed with a patient's serum containing $\mathrm{C}$ reactive proteins, an visible agglutination reaction will take place within 2 minutes.

\section{III- Serum $25(\mathrm{OH})$ vitamin D:}

Using a commercially available ELISA kit supplied by Perfect Ease Biotech (Beijing) Co., Ltd (China).Using TECAN spectra analyzer (China).

\section{Principle:}

The 25-OH vitamin D quantitative test kit is based on a solid phase enzyme-linked immunosorbent assay. The assay system utilizes one antibody for solid phase (microtiter wells) immobilization and another monoclonal antibody in the solutions.

The third antibody which recognize the second antibody conjugated with an enzyme (horseradish peroxidase). In the assay procedure, standards and test specimen (serum) are added to the Vitamin D (25-OH) antibody coated microtiter wells, incubation 30 minutes together with the second antibody. After wash, the third antibody labeled with horseradish peroxidase (conjugate) is added. If human Vitamin D $(25-\mathrm{OH})$ is present in the specimen, it will combine with the antibody on the well and the enzyme conjugate resulting in forming sandwiches between the solid phase and 
enzyme-linked antibodies. After incubation, the wells are washed with water to remove unbound labeled antibodies. A solution of TMB is added and incubated for 20 minutes, resulting in the development of a blue color. The color development is stopped with the addition of Stop Solution. The color is changed to yellow and measured spectrophotometrically at 450 $\mathrm{nm}$. The concentrations of Vitamin D are directly proportional to the color intensity of the test sample.

\section{Reagent \& samples preparation:}

All reagents \& samples were brought to room temperature for enough time. 1 volume of Wash Buffer Concentrate (50x) was diluted with 49 volumes of distilled water.

\section{Test Procedure:}

1. $\mathbf{1 0} \mu \mathrm{l}$ of standards $(7$ standards of concentrations of $0,5,10,20,50,100$ and 150 $\mathrm{ng} / \mathrm{ml}$ of $25-\mathrm{OH}$ vitamin $\mathrm{D}$, ready to use), controls and specimens were added into the appropriate wells with gentle and thoroughly mixing for 10 seconds were done.

2. $200 \mu \mathrm{l}$ of Sample Diluent added into each well. Mixing gently for 30 seconds followed by incubation at room temperature for 30 minutes was done.

3. The content of all wells were aspirated. The wells were rinsed and aspirated 5 times with

Results:

Table (1): Comparison between control group and cases group regarding demographic data

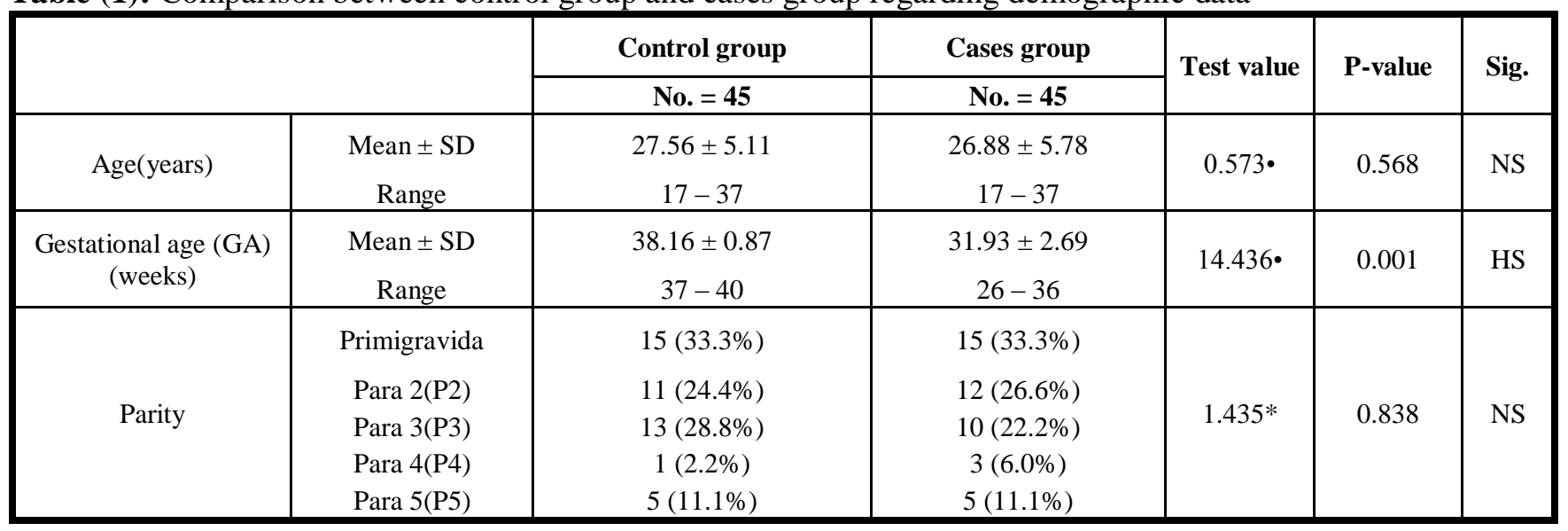

P-value >0.05: Non significant (NS); P-value <0.05: Significant (S); P-value < 0.01: highly significant (HS)

$*$ :Chi-square test; $\bullet$ : Independent t-test

This table showed that there was no statistically significant difference found between control group and patients group regarding age and parity while there was statistically significant difference between them regarding GA (weeks).

Table (2): Comparison between control group and cases group regarding history washing buffer. The plate was stroked sharply onto absorbent paper to remove all residual fluid droplets after each cycle.

4. $200 \mu \mathrm{l}$ of enzyme conjugate reagent was added into each well. Mixing gently for 30 seconds was done, and then incubated at room temperature for $30 \mathrm{~min}$.

5. The wells were aspirated and rinsed for 5 times with washing buffer. The plate was stroked sharply onto absorbent paper to remove all residual droplets.

6. $100 \mu \mathrm{l}$ of TMB substrate added into each well. Gently mixed for 10 seconds and incubated at room temperature (18-22C), in the dark, for 20 minutes.

7. The reaction was stopped by adding $\mathbf{1 0 0} \mu \mathrm{l}$ of Stop Solution to each well. Gently mixed for 10 seconds until the blue color completely changes to yellow.

8 . The optical density was read at $450 \mathrm{~nm}$ with a microtiter plate reader after 5 minutes minutes.

\section{Calculation of the results:}

A seven point's standard curve was made. The OD of the samples were plotted in the standard curve against their values in concentration. Then, the unknown serum concentrations were determined from the standard curve by interpolation. 


\begin{tabular}{|c|c|c|c|c|c|c|c|c|}
\hline & & \multicolumn{2}{|c|}{ Control group } & \multicolumn{2}{|c|}{ Cases group } & \multirow{2}{*}{$\begin{array}{c}\text { Test } \\
\text { value* }\end{array}$} & \multirow{2}{*}{ P-value } & \multirow{2}{*}{ Sig. } \\
\hline & & No. & $\%$ & No. & $\%$ & & & \\
\hline Family history & $\begin{array}{l}\text { - Negative } \\
\text { - H. of preterm labor in family }\end{array}$ & $\begin{array}{l}33 \\
12\end{array}$ & $\begin{array}{l}73.35 \% \\
26.65 \%\end{array}$ & $\begin{array}{l}25 \\
20\end{array}$ & $\begin{array}{l}55.5 \% \\
44.5 \%\end{array}$ & 3.276 & 0.070 & NS \\
\hline Medical history & $\begin{array}{l}\text { - Negative } \\
\text { - Any past surgical procedure }\end{array}$ & $\begin{array}{l}26 \\
19\end{array}$ & $\begin{array}{l}57.7 \% \\
42.3 \%\end{array}$ & $\begin{array}{l}28 \\
17\end{array}$ & $\begin{array}{l}62.2 \% \\
37.8 \%\end{array}$ & 0.195 & 0.659 & NS \\
\hline
\end{tabular}

P-value $>0.05$ : Non significant (NS); P-value $<0.05$ : Significant (S); P-value $<0.01$ : highly significant (HS)

*:Chi-square test

This table showed that there was no statistically significant difference found between control group and cases group regarding history of the studied cases.

Table (3): Vitamin D level in control and cases group regarding sufficient, insufficient and deficient groups.

\begin{tabular}{|c|c|c|c|c|c|}
\hline \multirow[t]{2}{*}{ Vitamin D level } & Control group & Cases group & \multirow[t]{2}{*}{ Test value } & \multirow[t]{2}{*}{ P-value } & \multirow[t]{2}{*}{ Sig. } \\
\hline & No. $=45$ & No. $=45$ & & & \\
\hline $\begin{array}{l}\text { Mean } \pm \text { SD } \\
\text { Range }\end{array}$ & $\begin{array}{c}16.15 \pm 8.63 \\
3-35.3\end{array}$ & $\begin{array}{c}10.93 \pm 4.40 \\
2-21.4\end{array}$ & $3.529 \bullet$ & 0.001 & HS \\
\hline $\begin{array}{c}\text { Sufficient } \\
\text { Insufficient } \\
\text { Deficient }\end{array}$ & $\begin{array}{c}17(37.8 \%) \\
10(22.2 \%) \\
18(40 \%)\end{array}$ & $\begin{array}{c}3(6.65 \%) \\
15(33.35 \%) \\
27(60 \%)\end{array}$ & $13.776^{*}$ & 0.001 & HS \\
\hline
\end{tabular}

P-value $>0.05$ : Non significant (NS); P-value <0.05: Significant (S); P-value $<0.01$ : highly significant (HS)

*:Chi-square test; $\bullet$ : Independent $\mathrm{t}$-test

This table showed that there was high statistically significant difference found between control group and cases group regarding Vitamin D level (ng/dl).

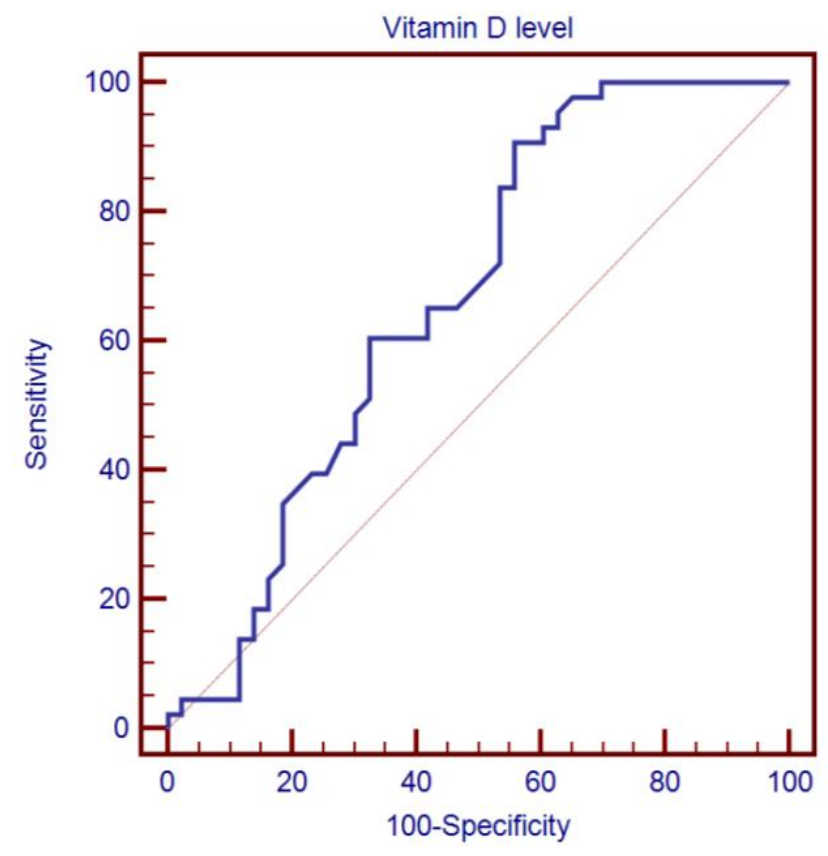

Figure (1): ROC curve for vitamin D cut off point.

Table (4): Vitamin D cut off point, sensitivity, specificity, positive predictive value (PPV) and negative predictive value (NPV).

\begin{tabular}{|c|c|c|c|c|c|c|}
\hline Parameter & AUC & Cut of Point & Sensitivity & Specificity & PPV & NPV \\
\hline Vitamin D level & $\mathbf{0 . 6 6 4}$ & $\leq 17.5$ & 90.70 & 44.19 & 61.9 & 82.6 \\
\hline
\end{tabular}


This ROC curve and Table (6) showed that the best cut off point between cases and controls regarding vitamin D level was found $\leq 17.5$ with sensitivity of $90.7 \%$, specificity of $44.19 \%$ and area under the curve (AUC) of $66.4 \%$.

Table (5): Relation between vitamin D level and parity, family history and medical history of the studied cases.

\begin{tabular}{|c|c|c|c|c|c|c|}
\hline & & \multicolumn{2}{|c|}{ Vitamin D level } & \multirow{2}{*}{$\begin{array}{c}\text { Test } \\
\text { value }\end{array}$} & \multirow{2}{*}{ P-value } & \multirow{2}{*}{ Sig. } \\
\hline & & Mean \pm SD & Range & & & \\
\hline Parity & $\begin{array}{c}\text { Primigravida } \\
\text { P2 } \\
\text { P3 } \\
\text { P4 } \\
\text { P5 }\end{array}$ & $\begin{array}{c}9.79 \pm 2.84 \\
11.68 \pm 5.90 \\
12.02 \pm 3.99 \\
11.87 \pm 4.47 \\
9.30 \pm 5.58\end{array}$ & $\begin{array}{l}7.00-17.50 \\
3.70-20.60 \\
7.40-21.40 \\
8.80-17.00 \\
2.00-15.60\end{array}$ & $0.620 \bullet \bullet$ & 0.651 & NS \\
\hline $\begin{array}{l}\text { Family } \\
\text { history }\end{array}$ & $\begin{array}{c}\text { Negative } \\
\text { H. of preterm labor in } \\
\text { family }\end{array}$ & $\begin{array}{l}10.56 \pm 4.27 \\
11.41 \pm 4.63\end{array}$ & $\begin{array}{l}2.00-21.40 \\
6.90-20.60\end{array}$ & $\begin{array}{c}-0.626 \\
\bullet\end{array}$ & 0.535 & NS \\
\hline $\begin{array}{l}\text { Medical } \\
\text { history }\end{array}$ & $\begin{array}{c}\text { Negative } \\
\text { Any past surgical } \\
\text { procedure }\end{array}$ & $\begin{array}{l}11.05 \pm 4.90 \\
10.74 \pm 3.56\end{array}$ & $\begin{array}{l}2.00-21.40 \\
7.00-18.40\end{array}$ & $0.224 \bullet$ & 0.824 & NS \\
\hline
\end{tabular}

:P-value >0.05: Non significant (NS); P-value <0.05: Significant (S); P-value < 0.01: highly significant (HS)

$\bullet:$ Independent t-test; $\bullet$ : One Way ANOVA test

This table showed that there was no statistically significant relation found between vitamin $\mathrm{D}$ level and parity and history of the studied patients.

Table (6): Relation between sufficient and deficient groups and Age, GA, and parity of the studied cases.

\begin{tabular}{|c|c|c|c|c|c|c|}
\hline & & Sufficient & Deficient & \multirow{2}{*}{ Test value } & \multirow{2}{*}{ P-value } & \multirow{2}{*}{ Sig. } \\
\hline & & No. $=26$ & No. $=19$ & & & \\
\hline Age & $\begin{array}{l}\text { Mean } \pm \text { SD } \\
\text { Range }\end{array}$ & $\begin{array}{c}27.84 \pm 5.34 \\
17-37\end{array}$ & $\begin{array}{c}27.17 \pm 4.89 \\
17-36\end{array}$ & 0.422 & 0.675 & NS \\
\hline GA (weeks) & $\begin{array}{c}\text { Mean } \pm \text { SD } \\
\text { Range }\end{array}$ & $\begin{array}{c}38.28 \pm 0.84 \\
37-40 \\
\end{array}$ & $\begin{array}{c}38.00 \pm 0.91 \\
37-39 \\
\end{array}$ & 1.041 & 0.304 & NS \\
\hline Parity & $\begin{array}{c}\text { Primigravida } \\
\text { P2 } \\
\text { P3 } \\
\text { P4 } \\
\text { P5 }\end{array}$ & $\begin{array}{c}8(30.8 \%) \\
7(26.9 \%) \\
8(30.8 \%) \\
0(0.0 \%) \\
3(11.5 \%) \\
\end{array}$ & $\begin{array}{c}8(42.2 \%) \\
4(21.1 \%) \\
5(26.3 \%) \\
1(5.2 \%) \\
1(5.2 \%)\end{array}$ & $2.435^{*}$ & 0.656 & NS \\
\hline
\end{tabular}

P-value $>0.05$ : Non significant (NS); P-value $<0.05$ : Significant (S); P-value $<0.01$ : highly significant (HS)

*:Chi-square test; $\bullet$ : Independent t-test

This table showed that there was no statistically significant difference found between sufficient and deficient group regarding age, gestational age and parity.

Table (7): Comparison between sufficient and deficient group regarding history.

\begin{tabular}{|c|c|c|c|c|c|c|c|c|}
\hline & & \multicolumn{2}{|c|}{ Sufficient } & \multicolumn{2}{|c|}{ Deficient } & \multirow{2}{*}{$\begin{array}{c}\text { Test } \\
\text { value* }\end{array}$} & \multirow{2}{*}{$\begin{array}{c}\mathbf{P}- \\
\text { value }\end{array}$} & \multirow{2}{*}{ Sig. } \\
\hline & & No. & $\%$ & No. & $\%$ & & & \\
\hline $\begin{array}{l}\text { Family } \\
\text { history }\end{array}$ & $\begin{array}{c}\text { Negative } \\
\text { H. of preterm labor in } \\
\text { family }\end{array}$ & $\begin{array}{l}19 \\
7\end{array}$ & $\begin{array}{l}73.0 \% \\
27.0 \%\end{array}$ & $\begin{array}{c}14 \\
5\end{array}$ & $\begin{array}{l}73.7 \% \\
26.3 \%\end{array}$ & 0.184 & 0.668 & NS \\
\hline $\begin{array}{l}\text { Medical } \\
\text { history }\end{array}$ & $\begin{array}{c}\text { Negative } \\
\text { Any past surgical } \\
\text { procedure }\end{array}$ & $\begin{array}{l}16 \\
10\end{array}$ & $\begin{array}{l}61.5 \% \\
38.5 \%\end{array}$ & $\begin{array}{c}11 \\
8\end{array}$ & $\begin{array}{l}57.8 \% \\
42.2 \%\end{array}$ & 0.085 & 0.771 & NS \\
\hline
\end{tabular}

P-value >0.05: Non significant (NS); P-value <0.05: Significant (S); P-value $<0.01$ : highly significant (HS)

*:Chi-square test

This table showed that there was no statistically significant difference found between sufficient and deficient group regarding history.

\section{Discussion:}

Incidence of preterm labor was $12 \%$ of all deliveries, and that of preterm deliveries due to
PROM 20.4\% and infections were the commonest causes of preterm labor ${ }^{(\mathbf{1 6})}$. 
Wagner et al. ${ }^{(17)}$ Showed that achieving a 25 $(\mathrm{OH}) \mathrm{D}$ serum concentration $40 \mathrm{ng} / \mathrm{ml}$ could significantly decrease the risk of PTB compared to concentrations $20 \mathrm{ng} / \mathrm{ml}$ after maternal supplementation with vitamin $\mathrm{D}$ during pregnancy. Other studies obtained different results. Thus, large, randomized controlled trials focusing on reducing PTB and its consequences were needed to accurately evaluate the potential benefits of these low-cost interventions in the future.

It is estimated that about 1 billion people worldwide are suffering from some degrees of vitamin D deficiency (VDD). Vitamin D deficiency is prevalent worldwide because of limited sun exposure and inadequate dietary sources $^{(18)}$.

This study was conducted on 90 subjects of pregnant females at labor. Their ages ranged from 14 to 40 years old. The current study was conducted in collaboration of the Clinical Pathology and Obs/Gyna Departments at AlHussein and Bab-Elshareyia University Hospitals, Faculty of Medicine, Al-Azhar University.

All participants were selected from the Obs/Gyna Department, Al-Hussein and BabElshareyia University Hospitals over a period from April, 2018 to July, 2018.

In the present study, an attempt was done to determine whether the level of vitamin D correlate with preterm labor or not in Egyptian pregnant females.

The subjects were divided into two groups; Group 1 (study group): Comprising 45 pregnant females in preterm labour ( $\leq 37$ weeks gestation). Group 2 (control group): Comprising 45 apparently healthy pregnant females in Full-term labour.

As regard serum vitamin $\mathrm{D}$, there was highly statistically significant decrease ( $p$ value $<0.001$ ) in vitamin $\mathrm{D}$ in patients group in comparison with the control group.

This study showed that $\mathbf{9 3 \%}$ of cases having preterm labor hadabnormally low $25(\mathrm{OH}) \mathrm{D}$ levels. Where $60 \%$ of patients showed deficient $25(\mathrm{OH}) \mathrm{D}(<12 \mathrm{ng} / \mathrm{ml}), \mathbf{3 3 \%}$ of patients showed insufficient $25(\mathrm{OH}) \mathrm{D}(>20$ and $<30$ $\mathrm{ng} / \mathrm{ml}$ ), while $\mathbf{7 \%}$ of cases showed normal vitamin D level.
In another study, $98.9 \%$ of preterm infants had vitamin D insufficiency or deficiency, and $51.1 \%$ of preterm infants were severely vitamin $\mathrm{D}$ deficient. These results showed much lower 25- OHD concentrations compared to those reported in previous studies of preterm infants (19) and were lower than those in previous reports on Korean newborns ${ }^{(20)}$.

In a polandian study, a significantly higher ratio of patients with severe vitamin D deficiency $(<$ $10 \mathrm{ng} / \mathrm{ml}$ ) in the group of patients had spontaneous preterm birth as compared to women with term delivery. The model of logistic regression created by us indicates a possible association between severe vitamin $\mathrm{D}$ deficiency and occurrence of preterm births. In addition, it has been found that the concentration of vitamin D below $15.84 \mathrm{ng} / \mathrm{ml}$ significantly increased the risk of preterm birth. The analysis of healthy-related behavior that may influence vitamin $D$ level also revealed the correlation between vitamin $\mathrm{D}$ and preterm birth. In the group of patients who supplemented vitamin D only periodically during their pregnancy, preterm births were more often. Currently, it is recommended to supplement vitamin D in doses of 2000 IU. In the population we analyzed, most patients used supplementation but the doses were below the currently recommended ones. We found that patients who declared avoiding the sun and not adequate time of daily exposure to sunlight also gave birth prematurely.

Further analysis of a group of patients with severe vitamin $\mathrm{D}$ deficiency also revealed the correlation between vitamin D level and its supplementation or exposure to sunlight. Additionally, the analysis of vitamin D levels after dividing patients into groups revealed that the mean level of vitamin D was lower in the group of births before 34 week of gestation (early preterm birth) than in the group of births between 34-36.6 week of gestation (late preterm birth). It might be concluded that an earlier birth time correlates with a lower vitamin D level. Severe deficiency was found in a bigger group of patients: as many as $14 \%$ of patients having term birth and as many as $34 \%$ of patients having preterm birth. Little is known about maternal vitamin $\mathrm{D}$ status in relation to risk of spontaneous preterm birth ${ }^{(21)}$.

Shibata et $\boldsymbol{a l} .{ }^{(22)}$ performed their study on a group of pregnant women in 30 th week of 
pregnancy and found a significantly lower vitamin D levels for patients hospitalized because of threatened premature delivery. The vitamin $\mathrm{D}$ level in that group was $11.2 \pm 3.2$ $\mathrm{ng} / \mathrm{ml}$ and was significantly lower as compared to healthy gravidas, demonstrating the level of $15.6 \pm 5.1 \mathrm{ng} / \mathrm{ml}$.

Bodnaret al. ${ }^{(23)}$ stated that abnormal vitamin $\mathrm{D}$ level below $(30 \mathrm{ng} / \mathrm{ml})$ was associated with the increased risk of preterm delivery in the case of women in twin pregnancy. In that study, blood was collected from all patients at week 24-28 of pregnancy. The study indicated that vitamin D level above $30 \mathrm{ng} / \mathrm{ml}$ decreased the risk of preterm birth by $60 \%$. The researchers stressed that demand for microelements, including vitamin $\mathrm{D}$, was different in the case of a twin pregnancy and singleton pregnancy, and standards of recommended supplementation should be different as well

High prevalence of vitamin D deficiency had been reported among pregnant women and neonates in different countries. Extensive research indicates that the prevalence of vitamin D deficiency varies from 18-84\% depending on factors such as ethnicity, region, culture and customs in different countries ${ }^{(24)}$. In the north of Canada, $46 \%$ of healthy mothers and $36 \%$ of their babies, in England $18 \%$ of pregnant women and $70 \%$ of their babies, in Northern India 84\%, and in New Zealand 61\% of pregnant women. In the Netherlands, 60$84 \%$ of pregnant women had vitamin D deficiency ${ }^{(25)}$.

A number of studies were conducted on estimating vitamin D deficiency in Iran and various estimates have been reported for pregnant women and neonates (26). These indicated that vitamin D deficiency is frequent among Iranian pregnant women and it can be inferred that majority of pregnant women suffer from vitamin D insufficiency. Note that these estimates were based on different categorization of vitamin D levels as the deficiency in each study refers to various ranges such as $<20,<25$, and $<35 \mathrm{ng} / \mathrm{ml}$. These studies have used different cut off points for assessing vitamin $\mathrm{D}$ deficiency. Considering the different opinions, a scale has been suggested dividing vitamin $\mathrm{D}$ concentrations into deficiency $(<50$ $\mathrm{nmol} / \mathrm{l})$, insufficiency (50-80 $\mathrm{nmol} / \mathrm{l})$ and optimal values $(>80 \mathrm{nmol} / \mathrm{l}){ }^{(27)}$.
These variations in the aforementioned studies compared to our results could be attributed to difference in genetic factors, difference in the environmental factors, variations in clinical cutoff, various units of measurement, method of assay or number of cases.

\section{Conclusion:}

Vitamin D deficiency occurs in the majority of preterm labour cases in Egypt. Therefore, decreased serum vitamin D levels are considered an additional risk factor in the pregnancy outcome.

\section{Recommendation:}

1- $\quad$ For better assessment of Vitamin D status, future studies should evaluate serum levels of $\mathrm{Ca}, \mathrm{Ph}$ and PTH to assess the cause of deficiency, which will help in better management.

2- In addition, it is recommended that to consider vitamin D supplementation and its efficacy as a new important line of prophylaxis in pregnant females, thereby prophylactic administration of vitamin $D$ could be useful and researches have to be done to approve this theory.

3- $\quad$ Screening for vitamin D deficiency seems of value in pregnant females.

4- $\quad$ Future studies are recommended to assess the association of vitamin $\mathrm{D}$ receptor gene polymorphisms to preterm labour.

5- $\quad$ Similar studies with more samples and accompanied by a control group is necessary for a better judgment.

\section{References:}

1. Rustico SE, Calabria AC, Garber SJ et al. (2014): Metabolic bone disease of prematurity. J. Clin. Transl. Endocrinol., 1 (3): $85-91$.

2. World Health Organization (2013): March of Dimes; Partnership for Maternal, Newborn, and Child Health; Save the Children; World Health Organization. Born Too Soon: The Global Action Report on Preterm Birth. Geneva, Switzerland: World Health Organization.

3. Martin JA, Osterman MJK, Sutton PD et al.(2010): Are Preterm Births on the Decline in the United States? Recent Data from the National Vital Statistics 
System. Hyattsville, MD: National Center for Health Statistics; https://www.ncbi.nlm.nih.gov/pubmed/206049 90

4. Blencowe $\mathrm{H}$, Cousens S, Oestergaard MZ et al. (2012): National, regional, and worldwide estimates of preterm birth rates in the year 2010 with time trends since 1990 for selected countries: a systematic analysis and implications. Lancet, 379: 2162-2172.

5. Liu NQ, Kaplan AT, Lagishetty V et al. (2011): Vitamin $D$ and the regulation of placental inflammation. J. Immunol., 186: 5968-5974.

6. Mulligan ML, Felton SK, Riek AE et al. (2010): Implications of vitamin $D$ deficiency in pregnancy and lactation. Am. J. Obstet. Gynecol., 202: 429.

7. De-Regil LM, Palacios C, Ansary A et al. (2012): Vitamin D supplementation for women during pregnancy. Cochrane Database Syst. Rev., 2: 25-28

8. Seamans KM, Cashman KD (2009): Existing and potentially novel functional markers of vitamin D status: a systematic review. Am. J. Clin. Nutr., 89: 1997-2008.

9. Leffelaar ER, Vrijkotte TG, van Eijsden M (2010): Maternal early pregnancy vitamin D status in relation to fetal and neonatal growth: results of the multi-ethnic Amsterdam Born Children and their Development cohort. Br. J. Nutr., 104: 108-17.

10. Fernández-Alonso AM, DionisSanchez EC, Chedraui $P$ et al. (2012): Firsttrimester maternal serum 25-hydroxyvitamin $\mathrm{D}(3)$ status and pregnancy outcome. Int. J. Gynaecol. Obstet., 116: 6-9.

11. Aghajafari F, Nagulesapillai T, Ronksley PE et al. (2013): Association between maternal serum 25-hydroxyvitamin D level and pregnancy and neonatal outcomes: systematic review and meta-analysis of observational studies. BMJ., 346: 1169.

12. Bilge U, Ünalacak M, Ünlüoglu I et al. (2015): Relationship between 1,25dihydroxy Vitamin D levels and homeostatic model assessment insulin resistance values in obese subjects. Niger J. Clin. Pract., 18 (3): $377-80$.
13. Volpe JJ (1992): Effect of cocaine use on the fetus. N. Engl. J. Med., 327: 399-407.

14. Sarker S, Kaplan C, Wiswell TE et al.(2005): Histologic chorioamnionitis and the risk of early intraventricular hemorrhage in infants born before28 weeks gestation. J. Perinatol., 46: 106.

15. Sykes L, MacIntyre DA, Yap XJ et al.(2012): Th2 dichotomy of pregnancy and preterm labour. Mediators Inflamm., 2012: 96117

16. Ross MG, Eden RD (2009): Preterm Labor. Available at http://emedicine. medscaned.comarticle/ 260998- print.

17. Wagner C, McNeil R, Johnson D et al. (2013): Health characteristics and outcomes of two randomized vitamin D supplementation trials during pregnancy: a combined analysis. J. Steroid Biochem. Mol. Biol., 136: 313-320.

18. Holick MF (2007): Vitamin D deficiency. N. Engl. J. Med., 18: 81-357.

19. Burris HH, Rifas-Shiman SL, Kleinman K (2012): Vitamin D deficiency in pregnancy and gestational diabetes mellitus. Am J Obstet Gynecol., 207: 182.e1-8.

20. Kim MS, Fujiki R, Murayama A, Kitagawa H, Yamaoka $K \quad$ (2007): 1Alpha,25(OH)2D3-induced transrepression by vitamin $\mathrm{D}$ receptor through E-box-type elements in the human parathyroid hormone gene promoter. MolEndocrinol., 21: 334-342.

21. Baczyńska-Strzecha M, Kalinka J (2017): Assessment of correlation between vitamin $d$ level and prevalence of preterm births in the population of pregnant women in poland. Am. J. Epidemiol., 179 (2): 168-176.

22. Shibata M, Suzuki A, Sekiya T et al. (2011): High prevalence of hypovitaminosis D in pregnant Japanese women with threatened premature delivery. J. Bone Miner Metab., 29 (5): 615-20.

23. Bodnar LM, Klebanoff MA, Gernand AD et al.(2014): Early-pregnancy vitamin $\mathrm{D}$ deficiency and risk of preterm birth subtypes. Obstet. Gynecol., doi:http://dx.doi. org/10.1097/AOG.0000000000000621

24. Kovacs C (2008): Vitamin D in pregnancy and lactation: maternal, fetal, and 
neonatal outcomes from human and animal studies. Am. J. Clin. Nutrition, 88: 520-528.

25. Pawley N, Bishop N (2004): Prenatal and infant predictors of bone health: The influence of vitamin D. The American Journal of Clinical Nutrition, 80 (6): 1748-1751.

26. Maghbooli $Z$, Hossein-Nezhad A, Shafaei AR et al. (2007): Vitamin D status in mothers and their newborns in Iran. BMC Pregnancy, 15: 32-36.

27. Hollis D, Hulsey TC, Ebeling M et al. (2011): Vitamin D supplementation during pregnancy: double-blind, randomized clinical trial of safety and effectiveness, J. Bone Miner. Res., 26 (10): 2341-2357. 